*УДК 658.155

Бабіч I.I., к.е.н., доцент

Луцький національний технічний університет

Патарідзе-Вишинська М.В.

ННЦ «Інститут аграрної економіки»

\title{
ЗАГРОЗИ ФІНАНСОВІЙ БЕЗПЕЦІ АГРАРНИХ ПІДПРИЄМСТВ УКРАЇНИ В УМОВАХ ЄВРОІНТЕГРАЦІЇ
}

Одним із важливих чинників незалежності держави за умов євроінтеграції є стан фінансової безпеки суб'єктів господарювання, особливо у стратегічному секторі економіки - сільському господарстві. Через нестабільність ринкового середовища постає потреба в комплексній превентивній оцінці зовнішніх та внутpiшніх факторів, що прямо чи опосередковано впливають на аграрний бізнес. В статті розглянуто умови, за яких може бути забезпечено пом'якшення впливу факторів ризику та підвищення конкурентоспроможності аграрних підприємств на європейському ринку.

Ключові слова: аграрні підприємства, фінансова безпека, фінансова стійкість, внутрішні та зовнішні загрози.

\section{Babich I., Pataridze-Vyshinska M. \\ THREATS TO THE FINANCIAL SECURITY OF UKRAINIAN AGRICULTURAL ENTERPRISES IN THE CONTEXT OF EUROPEAN INTEGRATION}

One of the important factors of state independence in the context of European integration is the state of financial security of economic entities, especially in the strategic sector of the economy - agriculture. Due to the volatility of the market environment, there is a need for comprehensive preventive assessment of external and internal factors that directly or indirectly affect the agricultural business.

The crisis situation in which most agricultural enterprises are located today poses a certain financial risk to both the socio-economic stability of the regions and the potential of each enterprise. The current state of the industry does not allow to ensure financial security of agricultural enterprises and food security of the country. Consequently, the competitiveness of such enterprises in the European market will be low.

Ukraine's integration into the EU is quite a difficult issue, as it has been going on for quite a long time, although it is clear that this process cannot proceed quickly.

There has been debate in Ukraine for more than one year about its integration choices, ie the choice of integration model: European or Eurasian. The Revolution of Dignity, the annexation of Crimea, and hostilities in eastern Ukraine have finally eliminated the polarity of the West-East movement and, finally, identified Ukrainian integration priorities for the European path of development.

* Бабіч I.І., Патарідзе-Вишинська М.В. 
We believe that the main threats to the financial security of Ukrainian agricultural enterprises in the context of European integration are the following: 1) Staffing; 2) Food pressure from Western partners; 3) Problems with obtaining a loan due to lack of own resources; 4) Low technological level; 5) Difficult political and economic situation; 6) Lack of state funding.

Agricultural enterprises have problems accessing long-term credit resources because they lack collateral sufficient to secure a refund. The article discusses the conditions under which the risk factors and the competitiveness of agricultural enterprises in the European market can be mitigated.

Key words: agricultural enterprises, financial security, financial stability, internal and external threats.

\section{Бабич И.И., Патаридзе-Вышинская М.В. УГРОЗЫ ФИНАНСОВОЙ БЕЗОПАСНОСТИ АГРАРНЫХ ПРЕДПРИЯТИЙ УКРАИНЫ В УСЛОВИЯХ ЕВРОИНТЕГРАЦИИ}

Одним из важных факторов независимости государства в условиях евроинтеграции является состояние финансовой безопасности субъектов хозяйствования, особенно в стратегическом секторе экономики - сельском хозяйстве. Из-за нестабильности рыночной среды возникает необходимость в комплексной превентивной оценке внешних и внутренних факторов, прямо или косвенно влияют на аграрный бизнес. В статье рассмотрены условия, при которых может быть обеспечено смягчения воздействия факторов риска и повышение конкурентоспособности аграрных предприятий на европейском рынке.

Ключевые слова: аграрные предприятия, финансовая безопасность, финансовая устойчивость, внутренние и внешние угрозы.

Постановка проблеми у загальному вигляді та ії̈ зв'язок 3 важливими науковими та практичними завданнями. Рівень фінансової безпеки кожного підприємства залежить від того, наскільки ефективно його управлінський персонал буде спроможний уникати можливих загроз та ліквідувати шкідливі наслідки окремих негативних впливів зовнішнього і внутрішнього середовищ, також наскільки ефективно, правильно та швидко аналітики будуть аналізувати діяльність, та те, як загрози впливають на різні ділянки, та які з них потребують негайного втручання.

Аналіз останніх досліджень, у яких започатковано вирішення проблеми. Проблеми сутності економічної та, зокрема, фінансової, безпеки досліджували А. Барановський, I. Саух, А. Берлач, 3. Верналій, Б. Губський, А. Городецький, Л. Доля, О. Користін, М. Корецький, Ю. Пахомов, В. Похилюк, А. Стовбчатий, В. 
Третяк та інші. У дослідження проблем взаємовідносин України з Європейським Союзом у частині розвитку сільського господарства в умовах глобалізаційних процесів та аналіз євроінтеграційних проблем України, зробили внесок такі зарубіжні і вітчизняні вчені як В. Юрчишин, Н.Антонюк, Н. Мусис, Д. Дайнен, О.Краєвська, Ю. Губені, В. Вардовський, П. Гайдуцький, П. Саблук, О. Шубравська, Г. Черевко та ін. Висновки, зроблені на основі досліджень вчених, дозволяють сформувати систему знань щодо перспектив забезпечення фінансової безпеки у євроінтеграційних умовах діяльності вітчизняного аграрного сектора економіки.

Цілі статті. Нашою метою є дослідити, яким чином в сучасних умовах господарювання та в умовах євроінтеграції система забезпечення економічної безпеки підприємства повинна вирішувати завдання: прогнозування та організація діяльності із попередження можливих загроз економічній безпеці підприємства, в тому числі і загроз, які виникають в умовах розширення ринків діяльності; виявлення, аналіз і оцінка наявних реальних загроз економічній безпеці підприємства, а також прийняття управлінських рішень щодо їх нівелювання; забезпечення фінансової стійкості, ліквідності та платоспроможності підприємства в будь-який момент часу; забезпечення технологічної незалежності та досягнення конкурентоспроможності продукції; підбір достатнього рівня кваліфікації персоналу та оцінка ефективності його функціонування; захист інформаційного середовища, комерційної таємниці та досягнення високого рівня інформаційного забезпечення роботи; забезпечення безпеки персоналу, капіталу, майна та комерційних інтересів; недопущення проникнення на підприємство структур економічної розвідки конкурентів, організованої злочинності та окремих осіб із протиправними намірами; вироблення найбільш оптимальних управлінських рішень щодо стратегії і тактики економічної діяльності підприємства; організація системи контролю за ефективністю функціонування системи безпеки, вдосконалення іiі елементів.

Виклад основного матеріалу дослідження з повним обгрунтуванням отриманих наукових результатів. Провідні науковці та практики постійно досліджують питання фінансової безпеки підприємств всіх галузей економіки. Так, Срмошенко М.М. та Горячева К.С. [1] зазначають, що загрози фінансовій безпеці підпри- 
ємства - це наявне чи потенційно можливе явище або чинник, яке створює небезпеку для реалізації фінансових інтересів підприємства.

Побудова системи економічної безпеки підприємства в умовах глобалізації ринку має здійснюватися на основі дотримання таких принципів [2]:

- законності (вся діяльність підприємства повинна здійснюватися на законних підставах);

- прав та свобод особи (система повинна забезпечувати економічну та правову безпеку кожного працівника й власника підприємства);

- системності та комплексності (кожен елемент системи може бути розглянутий як джерело та загроза економічній безпеці);

- раціональності та економічної ефективності (витрати на організацію та функціонування системи безпеки не повинні перевищувати доходи бізнесу);

- ієрархічного підпорядкування (у економічній системі повинна бути вибудувана чітка система повноважень і обов'язків кожного працівника, визначена ієрархічна система підпорядкування);

- безпосередності та безперервності (передбачає забезпечення постійної працездатності системи і поєднання превентивних та репресивних заходів забезпечення економічної безпеки).

Кваша О.С., Синякова А.В. [3] виділили в своїй науковій роботі загрози інтеграції України до $\mathrm{CC}$, та поділили на політичні, економічні та соціальні:

1. Політичні загрози: небезпека втягнення України в конфлікт цивілізацій між Заходом і мусульманським світом.

2. Економічні загрози: переміщення до України шкідливих виробництв; використання дешевої ресурсно-сировинної бази України; скорочення обсягів традиційного українського експорту до $\mathrm{EC}$; використання дешевої робочої сили України; витіснення національних товаровиробників із внутрішнього ринку; високі європейські ціни.

3. Соціальні загрози: поглиблення демографічного спаду; незаконна міграція населення та відплив кадрів; зростання безробіття.

Аналіз досліджень 3 проблеми внутрішніх та зовнішніх загроз агросектору України дав змогу узагальнити їх у табл. 1. 
"Економічні науки". - Серія "Облік і фінанси". - Випуск 16 (61). - 2019.

Таблиця 1

Внутрішні та зовнішні загрози економічній безпеці аграрного сектору України*

\begin{tabular}{|c|c|}
\hline Внутрішні загрози & Зовнішні загрози \\
\hline 1 & 2 \\
\hline $\begin{array}{c}\text { низька конкурентоспроможність, у тому } \\
\text { числі за рахунок високої собівартості } \\
\text { сільськогосподарської продукції та } \\
\text { продовольства національного виробни- } \\
\text { цтва на внутрішньому та зовнішньому } \\
\text { ринках } \\
\end{array}$ & $\begin{array}{c}\text { продовольчий тиск з боку } \\
\text { країн-партнерів }\end{array}$ \\
\hline $\begin{array}{c}\text { непоширеність висококонкурентних та } \\
\text { інноваційних технологій, адаптованих } \\
\text { до потреб й економічних можливостей } \\
\text { виробництва, низький рівень інновацій- } \\
\text { ності в аграрному секторі, низькі темпи } \\
\text { технікотехнологічної модернізації, а } \\
\text { отже, низький рівень продуктивності } \\
\text { праці } \\
\end{array}$ & $\begin{array}{c}\text { відтік кадрів шляхом закон- } \\
\text { ної та незаконної трудової } \\
\text { міграції у Свропейські краї- } \\
\text { ни }\end{array}$ \\
\hline $\begin{array}{c}\text { відсутність ефективної системи впрова- } \\
\text { дження наукових розробок в агропро- } \\
\text { мислове виробництво }\end{array}$ & $\begin{array}{c}\text { переміщення до України } \\
\text { шкідливих виробництв }\end{array}$ \\
\hline $\begin{array}{c}\text { зростання вартості невідновлювальних } \\
\text { природних ресурсів для сільськогоспо- } \\
\text { дарського виробництва }\end{array}$ & $\begin{array}{c}\text { використання дешевої ресу- } \\
\text { рсно-сировинної бази Украї- } \\
\text { ни }\end{array}$ \\
\hline $\begin{array}{c}\text { низька або неналежна якість окремих } \\
\text { видів сільськогосподарської сировини } \\
\text { та харчових продуктів }\end{array}$ & $\begin{array}{c}\text { скорочення обсягів тради- } \\
\text { ційного українського експо- } \\
\text { рту до ЄС } \\
\end{array}$ \\
\hline $\begin{array}{c}\text { виключення земель сільськогосподар- } \\
\text { ського призначення з економічного } \\
\text { обороту, обмеження можливостей дов- } \\
\text { гострокового інвестування в розвиток } \\
\text { сільськогосподарського виробництва та } \\
\text { звуженість застосування існуючих ме- } \\
\text { ханізмів використання речових прав на } \\
\text { землі сільськогосподарського призна- } \\
\text { чення }\end{array}$ & $\begin{array}{c}\text { використання дешевої робо- } \\
\text { чої сили України }\end{array}$ \\
\hline $\begin{array}{c}\text { відсутність моніторингу грунтів, з ме- } \\
\text { тою збереження їх родючості, управ- } \\
\text { ління якістю та раціонального викорис- } \\
\text { тання } \\
\end{array}$ & $\begin{array}{c}\text { витіснення національних } \\
\text { товаровиробників із внутрі- } \\
\text { шнього ринку }\end{array}$ \\
\hline
\end{tabular}


"Економічні науки". - Серія "Облік і фінанси". - Випуск 16 (61). - 2019.

Продовження табл. 1

\begin{tabular}{|c|c|}
\hline 1 & 2 \\
\hline $\begin{array}{c}\text { недостатньо розвинена інфраструктура } \\
\text { ринку сільськогосподарської продукції } \\
\text { та продовольства, недосконалість кана- } \\
\text { лів та умов просування сільськогоспо- } \\
\text { дарської продукції та продовольства на } \\
\text { міжнародний ринок }\end{array}$ & високі європейські ціни \\
\hline $\begin{array}{c}\text { недосконалість діючої системи інфор- } \\
\text { маційно-аналітичного забезпечення } \\
\text { розвитку галузі та її невідповідність } \\
\text { сучасним потребам системи управління } \\
\text { аграрним сектором } \\
\end{array}$ & фінансовий тиск МВФ \\
\hline $\begin{array}{c}\text { галузева незбалансованість сільського } \\
\text { господарства, суттєве переважання у } \\
\text { виробництві окремих видів сільського- } \\
\text { сподарської продукції або великих чи } \\
\text { дрібних товаровиробників } \\
\end{array}$ & $\begin{array}{c}\text { невідповідність високим } \\
\text { стандартам якості на ввізну } \\
\text { сільськогосподарську про- } \\
\text { дукцію }\end{array}$ \\
\hline $\begin{array}{c}\text { недостатня спеціалізація природних зон } \\
\text { щодо виробництва окремих видів про- } \\
\text { дукції }\end{array}$ & $\begin{array}{c}\text { запит на продукцію, що } \\
\text { виснажує земельні ресурси, } \\
\text { потребує поліпшення якості } \\
\text { земель та високих капіталь- } \\
\text { них вкладень } \\
\end{array}$ \\
\hline $\begin{array}{c}\text { слабка матеріально-технічна база селе- } \\
\text { кційно-насінницького комплексу, нау- } \\
\text { кових установ та їх дослідних госпо- } \\
\text { дарств }\end{array}$ & $\begin{array}{c}\text { обмеження доступу україн- } \\
\text { ських товарів на європейські } \\
\text { ринки під приводом їх не-- } \\
\text { відповідності європейським } \\
\text { стандартам і сертифікатам } \\
\end{array}$ \\
\hline $\begin{array}{c}\text { позиціонування на ринку як товарної } \\
\text { продукції сільськогосподарської проду- } \\
\text { кції, яка вироблялась для власного спо- } \\
\text { живання } \\
\end{array}$ & $\begin{array}{c}\text { обмеження інвестицій через } \\
\text { неврегульованість земельно- } \\
\text { го законодавства }\end{array}$ \\
\hline $\begin{array}{c}\text { недосконалість критеріїв надання дер- } \\
\text { жавної підтримки, які не повною мірою } \\
\text { враховують особливості технології } \\
\text { виробництва продукції рослинництва та } \\
\text { тваринництва за природно- } \\
\text { кліматичними зонами й регіонами, аг- } \\
\text { роекологічні вимоги до виробничо- } \\
\text { господарського процесу, інноваційність } \\
\text { технологій, показники економічної } \\
\text { ефективності виробництва та соціальну } \\
\text { відповідальність бізнесу }\end{array}$ & $\begin{array}{c}\text { вилучення з режиму вільної } \\
\text { торгівлі майже } 400 \text { товарних } \\
\text { позицій, в основному сільсь- } \\
\text { когосподарських товарів, } \\
\text { лібералізація експорту яких } \\
\text { на ринки ЄС була б для } \\
\text { України найбільш вигідною }\end{array}$ \\
\hline
\end{tabular}


"Економічні науки". - Серія "Облік і фінанси". - Випуск 16 (61). - 2019.

Продовження табл. 1

\begin{tabular}{|c|c|}
\hline 1 & 2 \\
\hline $\begin{array}{l}\text { слабка інвестиційна спроможність дер- } \\
\text { жави та переважної більшості суб’єктів } \\
\text { господарювання аграрного сектора, } \\
\text { недостатність власних обігових і досту- } \\
\text { пних кредитних фінансових ресурсів у } \\
\text { сільськогосподарських виробників для } \\
\text { покриття розриву в часі між потребою в } \\
\text { коштах та часом сприятливих цін реалі- } \\
\text { зації продукції }\end{array}$ & $\begin{array}{c}\text { запровадження з боку СС } \\
\text { для України дискримінацій- } \\
\text { ної системи тарифних квот } \\
\text { на дуже низькому рівні (для } \\
\text { більшості видів продукції ці } \\
\text { квоти становлять менше 6\% } \\
\text { від обсягу ринку ЄС із цих } \\
\text { видів продукції (зерно, м'ясо } \\
\text { тощо) } \\
\end{array}$ \\
\hline $\begin{array}{c}\text { недостатнє матеріальне стимулювання } \\
\text { працівників аграрного сектора }\end{array}$ & $\begin{array}{c}\text { скасування вивізного мита } \\
\text { на насіння соняшнику, що } \\
\text { може позбавити вітчизняні } \\
\text { переробні комбінати сиро- } \\
\text { вини } \\
\end{array}$ \\
\hline $\begin{array}{c}\text { дефіцит висококваліфікованих кадрів, } \\
\text { недосконала система прогнозування } \\
\text { потреби у кваліфікованих робітничих } \\
\text { кадрах та фахівцях з вищою освітою }\end{array}$ & $\begin{array}{c}\text { посилення конкуренції на } \\
\text { внутрішньому ринку, особ- } \\
\text { ливо в короткостроковій } \\
\text { перспективі, за рахунок } \\
\text { усунення тарифних і скоро- } \\
\text { чення нетарифних бар'єрів }\end{array}$ \\
\hline $\begin{array}{c}\text { низький попит населення на продукцію } \\
\text { сільського господарства та продовольс- } \\
\text { тво через низьку платоспроможність }\end{array}$ & $\begin{array}{l}\text { збереження в СС системи } \\
\text { багатомільярдних дотацій } \\
\text { аграрного сектора, що ро- } \\
\text { бить експорт української } \\
\text { продукції в ЄС та в третіх } \\
\text { країнах неконкурентоспро- } \\
\text { можним } \\
\end{array}$ \\
\hline $\begin{array}{c}\text { низька якість життя сільського населен- } \\
\text { ня порівняно з міським, знецінення } \\
\text { робочої сили в аграрному секторі, мо- } \\
\text { тиваційне відставання заробітної плати } \\
\text { в галузі відносно інших галузей народ- } \\
\text { ного господарства, відтак, втрата пра- } \\
\text { цівниками інтересу до ефективної праці } \\
\text { та отримання стабільних і достатніх } \\
\text { доходів за місцем проживання } \\
\end{array}$ & \multirow[t]{3}{*}{$\begin{array}{c}\text { дискримінаційне викорис- } \\
\text { тання праці сільського насе- } \\
\text { лення агрохолдингами } 3 \\
\text { іноземним капіталом, запро- } \\
\text { вадження ними екологічно } \\
\text { небезпечних технологій }\end{array}$} \\
\hline $\begin{array}{c}\text { зростання рівня безробіття економічно } \\
\text { активного населення на селі, втрата } \\
\text { інтелектуального потенціалу села } \\
\end{array}$ & \\
\hline $\begin{array}{c}\text { поглиблення демографічної кризи в } \\
\text { сільській місцевості }\end{array}$ & \\
\hline
\end{tabular}

*сформовано з використанням джерел $[4,10,11]$ 
Підсумовуючи, вважаємо, що основними загрозами фінансовій безпеці сільськогосподарських підприємств України в умовах євроінтеграції є такі:

- кадрове забезпечення;

- продовольчий тиск з боку західних партнерів;

- проблеми з отриманням кредиту через відсутність власних ресурсів;

- низький технологічний рівень;

- складна політична та економічна ситуація;

- недостатність державного фінансування.

Щодо кадрового забезпечення, наразі українським роботодавцям всіх сфер, зокрема і аграрної, бракує робочої сили. Причиною цього є низька заробітна плата, яка в свою чергу призводить до міграції працівників за кордон, де рівень життя є вищим і роботодавці можуть запропонувати значно вищі заробітні плати та пакет соціальних гарантів.

Згідно 3 дослідженням Міжнародної організації з міграції (MOM), в 2015 році з 700 тисяч українських мігрантів, які перебували в Європі, 3 \% було працевлаштовано на постійній основі в сфері сільського господарства і 11\% - на короткостроковій. Враховуючи, що темпи міграції з того часу не зменшились, а навіть зросли, то і ці цифри істотно зросли. Негативним також $є$ те, що працевлаштування в агросфері для молоді є непривабливим, непрестижним, незважаючи на потенціал даної сфери. Впливовим фактором на молодь $\epsilon$ віддаленість від міст, що влаштовує далеко не всіх, тим паче при невисокій заробітній платі.

Внаслідок недостачі робочої сили аграрії не в змозі працювати на повну потужність, що б дало змогу покращити фінансову ситуацію підприємств та дозволило їм конкурувати з європейськими суб' єктами господарювання.

Загрозою для економічної безпеки країни є певний продовольчий тиск з боку західних партнерів, які спонукають країну до застосування стратегії розвитку імпортозаміщення.

В сучасних умовах проблема імпортозаміщення набула гострого дискусійного характеру. Зіткнулися дві точки зору: 
1) імпортозаміщення повинно полягати в тому, щоб існуючих постачальників агропродукції замінити на постачальників 3 інших держав;

2) імпортозаміщення має на увазі налагодження власного виробництва продовольчих товарів.

Спроби держави створити умови для розширення бази самозабезпечення в продовольчій сфері не мають на меті дискредитувати іноземних виробників, а спрямовані, на захист національної економіки. При цьому, вирішуючи зазначену проблему, необхідно враховувати ризики, пов'язані 3 імпортозаміщенням, серед яких можна виділити такі: зниження конкурентоспроможності виробників та їхньої продукції за рахунок штучного зниження конкуренції 3 основними іноземними постачальниками; падіння ефективності всієї національної економіки, якщо імпортозаміщення продовольства виявляється за якісними характеристиками значно нижче аналогів продукції іноземних конкуруючих фірм; підвищення навантаження на бюджет.

Можна виділити два основних напрями реалізації програми імпортозаміщення в аграрному секторі економіки України. Перший напрям охоплює імпортні продовольчі товари, які вже виробляються в Україні, але в обмежених обсягах. Для цього важливо вирішити завдання модернізації вже існуючих сільськогосподарських підприємств для того щоб нарощувати виробництво необхідних обсягів продовольчої продукції. Другий напрям включає імпортні товари продовольчого призначення, які ще не виробляються в країні, але освоєння яких видається цілком можливим в короткостроковій перспективі. Відповідно в цьому випадку створення сучасних імпортозамінних господарств з гарантією конкурентоспроможності, як мінімум на внутрішньому ринку, має увійти до першочергових програм державної економічної політики.

Стратегія імпортозаміщення, витіснення з внутрішнього ринку продукції іноземного походження цілком в змозі не тільки вирішити проблему екстенсивного зростання сільського господарства, а й забезпечити якісний стрибок національного АПК на новій технологічній основі. Іншими словами, проведення політики імпортозаміщення передбачає створення стимулів для розвитку відста- 
лих галузей сільського господарства для забезпечення зростання їх конкурентоспроможності як на вітчизняному, так і на світовому ринку [5]. Але, все ж таки, необхідно боротися з причинами, які змушують аграріїв знаходитися у скрутному становищі і низькій конкурентоздатності для того, щоб європейські країни бачили, що Україна це сильна держава, яка допомагає своєму бізнесу, чим покращує своє становище.

Фінансова безпека сільськогосподарських підприємств в значній мірі залежить від їх фінансового стану, нині близько $30 \%$ господарств у сільськогосподарському секторі економіки збиткові, більше половини мають прострочену кредиторську заборгованість. Ціни на закупівлю продукції для виробників залишаються низькими, що не дозволяє їм своєчасно погашати отримані кредити і підштовхує кредитні організації до посилення вимог до позичальників i підвищення процентних ставок по кредитах. Основна частина сільськогосподарських підприємств не має власних ресурсів і можливості користуватися кредитами, тому і залишаються на досить низькому технологічному рівні більшість підприємств агропромислового комплексу України.

Кризовий стан, в якому перебуває сьогодні більшість аграрних підприємств, становить певну фінансову небезпеку, як для соціально-економічної стабільності регіонів, так і для потенціалу кожного підприємства. Сучасний стан галузі не дозволяє забезпечити фінансову безпеку сільськогосподарських підприємств і продовольчу безпеку країни [6]. А, отже, конкурентоздатність таких підприємств на європейському ринку буде низькою.

У сільськогосподарських підприємствах існують проблеми доступу до довгострокових кредитних ресурсів, оскільки в них відсутнє заставне майно, достатнє для забезпечення повернення коштів. В Україні на сьогодні існує мораторій на торгівлю сільськогосподарськими угіддями, а отже заборонено внесення права на землю як частки до статутних капіталів господарських товариств, продаж або інші види відчуження земельних ділянок та паїв, що знаходяться у приватній власності [7]. Тому, необхідно банкам та державі передивитися умови надання кредитів аграріям, пом'якшити їх, якщо країна хоче щоб аграрне підприємництво на- 
було подальшого розвитку. Дана ситуація знову ж таки, зменшує конкурентоспроможність аграрних підприємств на європейському ринку.

У 2014 році між Україною та Європейським Союзом було підписано Угоду про асоціацію України з СС, яка дає змогу перейти від партнерства і співробітництва до політичної асоціації та економічної інтеграції, яка означає процес зближення і поступового об'єднання національних економічних систем. Угода набрала чинності 1 вересня 2017 року. Для досягнення можливості інтегруватися до внутрішнього ринку ЄС Україна має привести свою систему технічного регулювання у відповідність до європейських вимог, оскільки головними перешкодами торгівлі з ЄС є вимоги до безпечності та якості продукції, іiі характеристик, процедури оцінки відповідності.

У довгостроковій перспективі угода має підвищити конкурентоспроможність товарів, що виробляються в Україні, а відтак, підвищити обсяг експорту на всесвітніх ринках. Окрім того, зі зростанням якості українських товарів зміцняться позиції національних виробників на внутрішньому ринку. Водночас українські споживачі матимуть доступ до якісніших і дешевших товарів і послуг [8].

Тобто, всі українські виробники мають забезпечити покращення якості своєї продукції, що в свою чергу потребує більших втрат коштів на нове технічне обладнання, можливо більш кваліфікованих працівників, інновації та інше. Це може спричинити зменшення кількості підприємців, в даному випадку аграріїв, тому що не кожен має змогу кардинально змінити чи удосконалити свою діяльність у і так доволі скрутному становищі. Комусь доводиться брати кредит, умови якого так само можуть негативно вплинути на діяльність у разі невдалого використання отриманих коштів. Але, 3 іншого боку це $є$ гарною можливістю вийти на нові ринки, розширювати виробництво, покращивши якість товарів, отримувати більші доходи, і мати змогу конкурувати з іноземними аграріями і в якості роботодавців, підвищивши заробітні плати працівникам, що в свою чергу має частково зупинити виїзд працівників за кордон.

Угода про асоціацію між Україною та СС передбачає запровадження поглибленої та всеохоплюючої зони вільної торгівлі між 
Україною та СС та спрямована на зменшення і скасування тарифів, які застосовуються сторонами щодо товарів, лібералізацію доступу до ринку послуг, а також на приведення українських правил та регламентів, що стосуються бізнесу, у відповідність до правил та регламентів СС із метою забезпечення вільного руху товарів і послуг між двома сторонами та взаємного недискримінаційного ставлення до аграрних підприємств, товарів і послуг на території України та €C.

Нині складна політична та економічна ситуація в країні значно впливає на стан аграрного сектору. Сталий розвиток сільського господарства України нині, як ніколи раніше, потребує більшої уваги з боку політики, важливу роль відіграють надання доступного фінансування, спрощення бюрократичних операцій, зниження корупції та підвищення стабільності українського законодавства.

Основними ж країнами, що активно експортують до інших країн СC, є Німеччина, Польща, Іспанія, Італія та Нідерланди. I якщо західноєвропейські країни вже понад півстоліття виглядають досить монолітною інтегрованою структурою, в тому числі економічно, то приклад Польщі, яка є членом ЄС лише 15 років, вказує на те, що ця країна знайшла своє місце на ринку агропродовольчої продукції Свропи [9].

Інтеграція України до ЄС є доволі непростим питанням, адже вона відбувається досить тривалий період, хоча й зрозуміло, що цей процес не може проходити швидко.

Не один рік в Україні точилися дискусії щодо ії інтеграційного вибору, тобто вибору моделі інтеграції: європейської чи євразійської. Революція гідності, анексія Криму та військові дії на сході України остаточно усунули полярність руху Захід - Схід i, нарешті, визначили українські інтеграційні пріоритети до європейського шляху розвитку.

Існують певні перешкоди на шляху поглиблення інтеграційних процесів між Україною та Свропейським Союзом:

- низький рівень поінформованості громадян про ЄС;

- сумніви стосовного того, що євроінтеграція матиме вигоду для всього населення України. Інтеграція України до СС може бути найбільш вигідною для країн - членів $\mathrm{CC}$, які хочуть підвищити 
свій геополітичний вплив і використовувати ресурси України у своїх інтересах;

- у населення є занепокоєність щодо конкурентоспроможності українських товарів на європейському ринку та еміграції робочої сили. Можливо, що внаслідок поглиблення співпраці з ЄС Україні загрожуватимуть висока конкуренція на європейському ринку продовольчих і промислових товарів, що залишить українську продукцію без шансів, та відтік значної маси кваліфікованих кадрів за кордон;

- сьогодні наріжний камінь розвитку відносин Україна - СС - це правосуддя, корупція та організована злочинність, і ці вимоги буде важко задовольнити Україні.

Однак, за оцінками експертів проєвропейської орієнтації, від впровадження Угоди про ЗВТ між СС та Україною остання може отримати чималі вигоди в сфері сільського господарства, зокрема внаслідок:

- зростання експорту української продукції в СС;

- розширення доступу на ринки третіх країн через гармонізацію стандартів з $\mathrm{CC}$;

- покращення інвестиційного клімату внаслідок пристосування національного законодавства до норм і правил СС;

- скасування субсидування експорту сільськогосподарської продукції з СС до України;

- поступове збільшення квот на експорт з України до СС окремих видів сільськогосподарської продукції [10].

Висновки. Отже, враховуючи вплив інтеграційних чинників на політичну, економічну та соціальну сфери держави, значно перспективнішим усе ж залишається вступ України до Європейського Союзу, на шляху до якого країна зробила вже багато зусиль та буде вдосконалюватися, щоб у найближчій перспективі стати членом ЄС. Хоча існує чимало загроз для підприємств, найголовнішою напевно є конкуренти, які вже встигли захопити європейський ринок, та частину українських працівників. Це можна також охарактеризувати як можливість вирватися вперед або ще більше погіршити становище України.

1. Срмошенко М. М., Горячева К.С. Фінансова складова економічної безпеки: держава і підприємство: наукова монографія. Київ, НАУ, 2010. 232 с. 
2. Олейников Е.А. Экономическая и национальная безопасность. Учебник. Москва, Издательство: Экзамен. 2005. 768 с.

3. Кваша О. С. Синякова А. В. Україна та СС: Проблеми та перспективи інтеграції в сучасних умовах URL: http://www.visnykeconom.uzhnu.uz.ua/archive/23_1_2019ua/25.pdf (дата звернення: 01.10.2019).

4. Лавренчук М. О. Загрози та шляхи забезпечення економічної безпеки в аграрному секторі. Науковий вісник Національної академії внутрішніх справ. 2013. № 2. C. 180-185. URL: http://nbuv.gov.ua/UJRN/Nvknuvs_2013_2_27 (дата звернення: 15.10 .2019$)$.

5. Залізнюк В. П. Імпортозаміщення в системі забезпечення продовольчої безпеки України. Державне управління: удосконалення та розвиток. 2019. № 1. URL: http://www.dy.nayka.com.ua/?op=1\&z=1374 (дата звернення: 15.10.2019).

6. Біляк Ю. В. Особливості фінансової безпеки сільськогосподарського підприємства в загальній системі АПК. Агросвіт. 2019. № 3. С. 24-29. DOI: $10.32702 / 2306-6792.2019 .3 .247$.

URL: http://www.agrosvit.info/?op=1\&z=2803\&i=3 (дата звернення: 15.10.2019).

7. Пристемський О. С. Фінансова безпека як базис розвитку сільського господарства . Науковий вісник Херсонського державного університету. Сер. : Економічні науки. 2014. Вип. 8(7). С. 125-128. URL: http://nbuv.gov.ua/UJRN/Nvkhdu_en_2014_8\%287\%29_31 (дата звернення: 20.10.2019).

8. Угода про асоціацію між Україною та Європейським Союзом. URL: https://uk.wikipedia.org/wiki/\%D0\%A3\%D0\%B3\%D0\%BE\%D0\%B4\%D0\%B0_\% D0\%BF\%D1\%80\%D0\%BE_\%D0\%B0\%D1\%81\%D0\%BE\%D1\%86\%D1\%96\%D0 \%B0\%D1\%86\%D1\%96\%D1\%8E_\%D0\%BC\%D1\%96\%D0\%B6_\%D0\%A3\%D0\% BA\%D1\%80\%D0\%B0\%D1\%97\%D0\%BD\%D0\%BE\%D1\%8E_\%D1\%82\%D0\%B 0_\%D0\%84\%D0\%B2\%D1\%80\%D0\%BE\%D0\%BF\%D0\%B5\%D0\%B9\%D1\%81\% D1\%8C\%D0\%BA\%D0\%B8\%D0\%BC_\%D0\%A1\%D0\%BE\%D1\%8E\%D0\%B7\% D0\%BE\%D0\%BC (дата звернення: 20.10.2019).

9. Експорт української агропродовольчої продукції до європейського Союзу в умовах глибокої та всеосяжної зони вільної торгівлі. URL: http://ucab.ua/files/Survey/Doslidjenna/Manual_UCAB.pdf (дата звернення: 20.10.2019).

10. Чеканська Л.А. Євроінтеграційні процеси України та їх вплив на інвестування в АПК. Ефективна економіка № 10, 2014. URL: http://www.economy.nayka.com.ua/?op=1\&z=3459 (дата звернення: 20.10.2019).

11. Гайдуцький П. Україна - СС: проблеми інтеграції . Джерело тижня 7 червня 2013 року. URL: http://agroconf.org/content/gayduckiyukraina-es-problemyintegracii (дата звернення: 25.10.2019). 